\title{
ВІДТВОРЮВАЛЬНІ ЯКОСТІ СВИНОМАТОК ВЕЛИКОЇ БІЛОЇ ПОРОДИ РІЗНОӦ ВНУТРІПОРОДНОЇ ДИФЕРЕНЦІАЦІЇ ЗА ІНДЕКСОМ «РІВЕНЬ АДАПТАЦІЇ» ТА ЕКОНОМІЧНА ЕФЕКТИВНІСТЬ ЇХНЬОГО ВИКОРИСТАННЯ
}

\author{
Халак Віктор Іванович \\ кандидат сільськогосподарських наук, ст. науковий співробітник \\ Державна установа Інститут зернових культур НААН України \\ ORCID: 0000-0002-4384-6394 \\ E-mail: v16kh91@gmail.com
}

В роботі наведено результати досліджень показників довготривалої адаптації та відтворювальних якостей свиноматок великої білої породи, розраховано показники мінливості ознак та їх кореляційний зв'язок, а також економічну есрективність результатів досліджень. Експериментальну частину роботи проведено в агрофоормуваннях Дніпропетровської області (ТОВ «АФ «Дзержинець», ТОВ «Відродження») та лабораторії тваринництва Державної установи Інститут зернових культур НААН. Робота виконана згідно ПНД НААН №30 «Інноваиійні технології племінного, промислового та органічного виробництва продукиії свинарства («Свинарство»). Об'єктом досліджень були основні свиноматки великої білої породи. Оцінку тварин зазначеної виробничої групи та породи за показниками рівня адаптації та відтворювальних якостей проводили з урахуванням наступних кількісних ознак: тривалість життя (ТЖ), міс; тривалість племінного використання (ТПВ), міс; одержано опоросів за період племінного використання, одержано поросят усього, гол; багатоплідність, гол; маса гнізда на час відлучення у віці 28 діб, ке; збереженість поросят до відлучення, \%. Індекс «рівень адаптації розраховували за методикою В.С. Смірнова (2003), індекс відтворювальних якостей свиноматки - за методикою М.Д. Березовського (П.А. Ващенко, 2019). Встановлено, що тривалість життя свиноматок основного стада становить 44,1 місяців, тривалість племінного використання - 32,8 місяців, індекс «рівень адаптації» - 11,87 балів. За показниками багатоплідності та маси гнізда на час відлучення тварини основного стада належать до I класу та класу еліта. 3 урахуванням внутріпородної дифференціації за індексом «рівень адаптаціїі свиноматки класу $M$ - достовірно переважали ровесниць класу $M^{+}$за тривалістю життя, тривалістю племінного використання і індексом «рівень адаптації» 6 середньому на 64,11%. Достовірну різницю між групами тварин зазначених класів встановлено за багатоплідністю (2,0 гол, $t d=2,22)$, масою гнізда на час відлучення у віці 28 діб, ке (5,9 ке, $t d=2,56)$, індексом відтворювальних якостей свиноматки (індекс М.Д. Березовського) (3,9 бала, $t d=2,60)$. Коефріцієнти парної кореляції між ознаками, що характеризують рівень aдаптації та відтворювальні якості свиноматок коливаються у межах від -0,704 (tr=10,80) до +0,982 (tr=213,05). Використання свиноматок великої білої породи класу $M$ - за індексом «рівень адаптації» забезпечує одержання максимальної прибавки продукиії (+5,71\%).

Ключові слова: свиноматка, тривалість життя, тривалість племінного використання, відтворювальні якості, індекс, рівень адаптації, економічна ефективність, мінливість, кореляція.

DOI: https://doi.org/10.32845/bsnau.lvst.2021.1.14

Результати наукових досліджень та досвід роботи спеціалістів агроформувань свідчать, що важливим критерієм відбору свиноматок, що перевіряються до групи основних $€$ їх оцінка за показниками відтворювальних якостей за результатами першого та наступних опоросів, а також за основними параметрами, що характеризують рівень їх адаптації до умов навколишнього середовища [1-3]. При цьому використовують ряд методів, які дають можливість ефективно вести відбір високопродуктивних тварин та формувати популяцію тварин за основними групами кількісних ознак.

Підтвердженням актуальності даного напрямку досліджень $€$ результати роботи вітчизняних та зарубіжних вчених [4-8].

Мета роботи - дослідити показники довготривалої адаптації та відтворювальних якостей свиноматок великої білої породи, розрахувати показники мінливості ознак та їх кореляційний зв'язок, а також економічну ефективність результатів досліджень.

Матеріал і методика досліджень. Дослідження проведено в агроформуваннях Дніпропетровської області (ТОВ «АФ «Дзержинець», ТОВ «АФ «Відродження») та лабораторії тваринництва Державної установи Інститут зернових культур НААН. Робота виконана згідно програми наукових досліджень НААН України №31 «Генетичне поліпшення сільськогосподарських тварин, їх відтворення та збереження

біорозмаїття» («Генетика, збереження та відтворення біоресурсів у тваринництві»), завдання - 31.02.01.18.П. «Визначити адаптаційні особливості та характер успадкування полігенно-спадкових ознак свиней різних генотипів та розробити інтегровану систему створення високопродуктивної популяції».

Об'єктом досліджень були основні свиноматки великої білої породи. Оцінку тварин зазначеної виробничої групи та породи за показниками рівня адаптації та відтворювальних якостей проводили з урахуванням наступних кількісних ознак: тривалість життя (ТЖ), міс; тривалість племінного використання (ТПВ), міс; одержано опоросів за період племінного використання, одержано поросят усього, гол; багатоплідність, гол; маса гнізда на час відлучення у віці 28 діб, кг; збереженість поросят до відлучення, \%.

Індекс «рівень адаптації» (1), індекс відтворювальних якостей свиноматки та економічну ефективність проведених досліджень (3) розраховували за формулами:

$$
P A=T \Psi^{2} /(\text { кількість опоросів } \times \text { TПB })
$$

де: $P A$ - індекс «рівень адаптації», балів; ТЖ - тривалість життя свиноматки (від народження до останнього відлучення поросят), міс.; ТПВ - тривалість племінного використання (від початку першої поросності до останнього відлучення поросят), міс. [9];

$$
I=B+(2 \times H)+(35 \times G),
$$

Вісник Сумського національного аграрного університету 
де: I - індекс відтворювальних якостей свиноматки (індекс М.Д. Березовського), балів; $B$ - кількість живих поросят на час народження, гол; $H$ - кількість поросят на час відлучення, гол; $\mathrm{G}$ - середньодобовий приріст живої маси поросят до відлучення, кг [10];

$$
E=Ц \times((C \times \Pi) / 100) \times Л \times K)),
$$

де: $E$ - вартість додаткової продукції, грн.; Ц - закупівельна ціна одиниці продукції, відповідно існуючих цін, які діють в Україні; C - середня продуктивність тварин; П середня надбавка основної продукції (\%), яка виражена у відсотках на 1 голову при застосуванні нового і поліпшеного селекційного досягнення порівняно з продуктивністю тварин базового використання; Л - постійний коесріцієнт зменшення результату, який пов'язаний з додатковими витратами на прибуткову продукцію $(0,75) ; K$ - чисельність поголів'я сільськогосподарських тварин нового або поліпшеного селекційного досягнення, голів [11].

Біометричну обробку одержаного матеріалу проводили за методиками Лакіна Г.Ф. [12] з використанням програмованого модуля «Аналіз даних» в Microsoft Excel.

Результати досліджень. Встановлено, що тривалість життя свиноматок основного стада становить

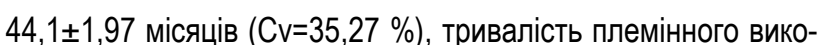
ристання - 32,8 $\pm 1,95$ місяців (Cv=46,91\%), індекс «рівень

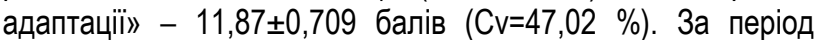
племінного використання від свиноматок великої білої породи підконтрольної популяції одержано $6,1 \pm 0,36$ опоросів ( $\mathrm{Cv}=47,11 \%)$, поросят усього $-65,8 \pm 4,41$ гол ( $\mathrm{Cv}=52,80 \%)$,

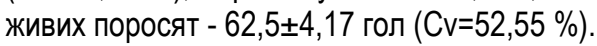

Середній показник багатоплідності становить $10,2 \pm 0,20$ поросят на один опорос ( $\mathrm{Cv}=16,02 \%)$, маса гнізда

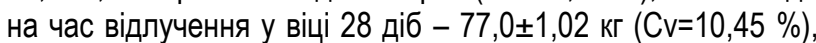
збереженість поросят до відлучення - 95,0 \%.

Результати дослідження зазначених показників свиноматок різних класів розподілу за індексом «рівень адаптації» наведено у таблиці 1.

Встановлено, що свиноматки класу М- за показником «тривалість життя (ТЖ), міс» переважали ровесниць класу $\mathrm{M}^{+}$на 32,1 міс (td=10,15; $\left.\mathrm{P}<0,001\right)$, «тривалість племінного використання (ТПВ), міс» - 35,1 міс (td=13,65; $\mathrm{P}<0,001)$, «одержано опоросів за період племінного використання» 7,1 (td=15,43; $P<0,001)$, «індекс «рівень адаптації» - 14,27 балів $(\mathrm{td}=6,39 ; \mathrm{P}<0,001)$

Тривалість життя, племінного використання і відтворювальні якості свиноматок різних класів розподілу за індексом «рівень адаптації»

\begin{tabular}{|c|c|c|c|c|}
\hline \multirow{4}{*}{ Показники, одиниці виміру } & \multirow{4}{*}{$\begin{array}{l}\text { Біометричні } \\
\text { показники }\end{array}$} & \multicolumn{3}{|c|}{ Індекс «рівень адаптації», балів } \\
\hline & & $16,61-39,62$ & $8,48-15,41$ & $6,55-8,08$ \\
\hline & & \multicolumn{3}{|c|}{ клас розподілу } \\
\hline & & $\mathrm{M}^{+}$ & $\mathrm{M}^{0}$ & $\mathrm{M}^{-}$ \\
\hline \multirow{4}{*}{ Тривалість життя (ТЖ), міс } & $\mathrm{n}$ & 10 & 34 & 15 \\
\hline & $\overline{\mathrm{X}} \pm S \bar{x}$ & $26,5 \pm 2,32$ & $42,2 \pm 2,45$ & $58,6 \pm 2,16$ \\
\hline & $\sigma \pm S_{\sigma}$ & $7,33 \pm 1,639$ & $14,30 \pm 1,735$ & $8,38 \pm 1,531$ \\
\hline & $\mathrm{C}_{\mathrm{v}} \pm \mathrm{S}_{\mathrm{Cv}}, \%$ & $27,60 \pm 6,174$ & $33,88 \pm 4,111$ & $14,30 \pm 2,614$ \\
\hline \multirow{3}{*}{ Тривалість племінного використання (ТПВ), міс } & $\overline{\mathrm{X}} \pm S \bar{x}$ & $14,0 \pm 1,39$ & $30,5 \pm 2,16$ & $49,1 \pm 2,17$ \\
\hline & $\sigma \pm S_{\sigma}$ & $4,40 \pm 0,984$ & $12,64 \pm 1,533$ & $8,41 \pm 1,537$ \\
\hline & $\mathrm{C}_{\mathrm{v}} \pm \mathrm{S}_{\mathrm{cv}}, \%$ & $31,42 \pm 7,123$ & $41,44 \pm 5,029$ & $17,12 \pm 3,129$ \\
\hline \multirow{3}{*}{$\begin{array}{l}\text { Одержано опоросів за період племінного } \\
\text { використання }\end{array}$} & $\overline{\mathrm{X}} \pm S \bar{x}$ & $2,5 \pm 0,30$ & $5,4 \pm 0,34$ & $9,6 \pm 0,36$ \\
\hline & $\sigma \pm S_{\sigma}$ & $0,97 \pm 0,217$ & $2,00 \pm 0,242$ & $1,40 \pm 0,255$ \\
\hline & $\mathrm{C}_{\mathrm{v}} \pm \mathrm{S}_{\mathrm{cv},} \%$ & $38,87 \pm 8,695$ & $37,03 \pm 4,493$ & $14,58 \pm 2,665$ \\
\hline \multirow{3}{*}{ Індекс «рівень адаптації», балів } & $\overline{\mathrm{X}} \pm S \bar{x}$ & $21,59 \pm 2,236$ & $11,16 \pm 0,364$ & $7,32 \pm 0,118$ \\
\hline & $\sigma \pm S_{\sigma}$ & $7,07 \pm 1,581$ & $2,12 \pm 0,257$ & $0,45 \pm 0,082$ \\
\hline & $\mathrm{C}_{\mathrm{v}} \pm \mathrm{S}_{\mathrm{cv},} \%$ & $32,74 \pm 7,324$ & $18,99 \pm 2,304$ & $6,14 \pm 1,122$ \\
\hline \multirow{3}{*}{ Одержано поросят усього, гол } & $\overline{\mathrm{X}} \pm S \bar{x}$ & $23,6 \pm 3,78$ & $58,0 \pm 4,19$ & $106,2 \pm 5,48$ \\
\hline & $\sigma \pm S_{\sigma}$ & $11,98 \pm 2,680$ & $24,47 \pm 2,969$ & $21,25 \pm 3,884$ \\
\hline & $\mathrm{C}_{\mathrm{v}} \pm \mathrm{S}_{\mathrm{cv}}, \%$ & $50,76 \pm 11,355$ & $42,18 \pm 5,118$ & $20,00 \pm 3,65$ \\
\hline \multirow{3}{*}{ Одержано живих поросят усього, гол } & $\overline{\mathrm{X}} \pm S \bar{x}$ & $21,4 \pm 3,60$ & $55,7 \pm 3,96$ & $100,8 \pm 4,91$ \\
\hline & $\sigma \pm S_{\sigma}$ & $11,38 \pm 2,545$ & $23,13 \pm 2,807$ & $19,02 \pm 3,477$ \\
\hline & $\mathrm{C}_{\mathrm{v}} \pm \mathrm{S}_{\mathrm{cv}}, \%$ & $53,17 \pm 11,894$ & $41,52 \pm 5,038$ & $18,86 \pm 3,44$ \\
\hline \multirow{3}{*}{ Багатоплідність, гол } & $\overline{\mathrm{X}} \pm S \bar{x}$ & $8,5 \pm 0,88$ & $10,3 \pm 0,17$ & $10,5 \pm 0,25$ \\
\hline & $\sigma \pm S_{\sigma}$ & $2,79 \pm 0,624$ & $1,02 \pm 0,123$ & $0,97 \pm 0,177$ \\
\hline & $\mathrm{C}_{\mathrm{v}} \pm \mathrm{S}_{\mathrm{Cv}}, \%$ & $32,82 \pm 7,342$ & $9,99 \pm 1,212$ & $9,23 \pm 1,687$ \\
\hline \multirow{3}{*}{ Маса гнізда на час відлучення у віці 28 діб, кг } & $\overline{\mathrm{X}} \pm S \bar{x}$ & $75,5 \pm 1,90$ & $76,7 \pm 1,52$ & $81,4 \pm 1,37$ \\
\hline & $\sigma \pm S_{\sigma}$ & $6,02 \pm 1,346$ & $8,90 \pm 1,080$ & $5,34 \pm 0,976$ \\
\hline & $\mathrm{C}_{\mathrm{v}} \pm \mathrm{S}_{\mathrm{Cv}}, \%$ & $7,97 \pm 1,782$ & $11,60 \pm 1,407$ & $6,56 \pm 1,199$ \\
\hline Збереженість, \% & $\overline{\mathrm{X}} \pm S \bar{x}$ & $95,5 \pm 1,84$ & $92,2 \pm 0,94$ & $94,3 \pm 1,79$ \\
\hline \multirow{3}{*}{$\begin{array}{l}\text { Індекс відтворювальних якостей свиноматки (індекс } \\
\text { М.Д. Березовського), балів }\end{array}$} & $\overline{\mathrm{X}} \pm S \bar{x}$ & $34,53 \pm 1,410$ & $36,89 \pm 0,368$ & $38,43 \pm 0,586$ \\
\hline & $\sigma \pm S_{\sigma}$ & $4,46 \pm 0,997$ & $2,14 \pm 0,259$ & $2,27 \pm 0,414$ \\
\hline & $\mathrm{C}_{\mathrm{v}} \pm \mathrm{S}_{\mathrm{Cv}}, \%$ & $12,91 \pm 2,888$ & $5,80 \pm 0,703$ & $5,90 \pm 1,078$ \\
\hline
\end{tabular}

Різниця між зазначеними групами піддослідних тварин за показником «одержано поросят усього, гол» дорівнює 82,6 
гол (td=12,42; $\mathrm{P}<0,001)$, «одержано живих поросят усього, гол» - 79,4 гол ( $\mathrm{dd}=13,05 ; \mathrm{P}<0,001)$, «багатоплідність, гол» - 2,0 го $(\mathrm{td}=2,22 ; \mathrm{P}<0,05)$, «маса гнізда на час відлучення у віці 28 діб, кг» - 5,9 кг ( $\mathrm{td}=2,56 ; \mathrm{P}<0,01)$, «індекс відтворювальних якостей свиноматки (індекс М.Д. Березовського) - 3,9 бала (td=2,60; $\mathrm{P}<0,01)$.

Коефіцієнт мінливості ознак, що характеризує рівень адаптації та відтворювальні якості свиноматок підконтрольного стада коливається у межах від 5,80 (клас розподілу свиноматок за індексом «рівень адаптації» - М0, показник - індекс відтворювальних якостей свиноматки (індекс М.Д. Березовського), балів) до 53,18 \% (клас розподілу свиноматок за індексом «рівень адаптації» - $\mathrm{M}^{+}$, показник - одержано живих поросят усього, гол) .

Результати розрахунків коефіцієнта парної кореляції між ознаками, що характеризують рівень адаптації свиней та показниками відтворювальних якостей наведено в таблиці 2.

Коефіцієнти парної кореляції між ознаками, що характеризують рівень адаптації свиней

Таблиця 2 та показниками відтворювальних якостей

\begin{tabular}{|c|c|c|c|}
\hline \multicolumn{2}{|l|}{ Показник (ознака) } & \multicolumn{2}{|c|}{ Біометричні показники } \\
\hline$x$ & $y$ & $\mathrm{r} \pm \mathrm{Sr}$ & $\operatorname{tr}$ \\
\hline \multirow{7}{*}{ Тривалість життя (ТЖ), міс } & 1 & $0,951 \pm 0,0124$ & 7,70 \\
\hline & 2 & $0,939 \pm 0,0153$ & 61,45 \\
\hline & 3 & $0,940 \pm 0,0150$ & 62,51 \\
\hline & 4 & $0,415 \pm 0,1069$ & 3,88 \\
\hline & 5 & $0,197 \pm 0,1242$ & 1,59 \\
\hline & 6 & $-0,147 \pm 0,1264$ & 1,16 \\
\hline & 7 & $0,409 \pm 0,1076$ & 3,80 \\
\hline \multirow{7}{*}{$\begin{array}{l}\text { Тривалість племінного використання } \\
\text { (ТПВ), міс }\end{array}$} & 1 & $0,969 \pm 0,0079$ & 122,87 \\
\hline & 2 & $0,980 \pm 0,0510$ & 191,55 \\
\hline & 3 & $0,982 \pm 0,0046$ & 213,05 \\
\hline & 4 & $0,405 \pm 0,1080$ & 3,75 \\
\hline & 5 & $0,214 \pm 0,1233$ & 1,74 \\
\hline & 6 & $-0,123 \pm 0,1272$ & 0,97 \\
\hline & 7 & $0,415 \pm 0,1069$ & 3,88 \\
\hline \multirow{7}{*}{ Індекс «рівень адаптації», балів } & 1 & $-0,704 \pm 0,0652$ & 10,80 \\
\hline & 2 & $0,980 \pm 0,0051$ & 191,55 \\
\hline & 3 & $0,982 \pm 0,0046$ & 213,05 \\
\hline & 4 & $0,405 \pm 0,1080$ & 3,75 \\
\hline & 5 & $0,214 \pm 0,1233$ & 1,74 \\
\hline & 6 & $-0,123 \pm 0,1272$ & 0,977 \\
\hline & 7 & $0,415 \pm 0,1069$ & 3,88 \\
\hline
\end{tabular}

Примітка: 1 - одержано опоросів за період племінного використання; 2 - одержано поросят усього, гол; 3 - одержано живих поросят усього, гол; 4 - багатоплідність, гол; 5 - маса гнізда на час відлучення у віці 28 діб, ке; 6- збереженість, \%; 7 - індекс відтворювальних якостей свиноматки (індекс М. Д. Березовського), балів.

Коефріцієнт парної кореляції між ознаками, що характеризують рівень адаптації свиней та показниками відтворювальних якостей коливається у межах від $-0,704$ ( $\mathrm{tr}=10,80)$ до +0,982 (tr=213,05).

Достовірні коефіцієнти кореляції встановлено за наступними парами ознак ( $\mathrm{n}=59)$ : тривалість життя $\times$ одержано опоросів ( $r=0,951)$, тривалість життя $x$ одержано поросят усього (r=0,939), тривалість життя $\times$ одержано живих поросят $(r=0,940)$, тривалість життя $\times$ багатоплідність $(r=0,415)$, тривалість життя $\times$ індекс відтворювальних якостей свиноматки (індекс М. Д. Березовського) (r=0,409), тривалість племінного використання $\times$ одержано опоросів ( $r=0,969)$, тривалість племінного використання $\times$ одержано поросят усього ( $r=0,980)$, тривалість племінного використання $x$ одержано живих поросят ( $r=0,982)$, тривалість племінного використання $\times$ багатоплідність $(r=0,405)$, індекс «рівень адаптації» $x$ одержано опоросів $(r=-0,704), x$ одержано поросят усього $(r=0,980), \quad x$ одержано живих поросят $(r=0,982), \times$ багатоплідність $(r=0,405)$, індекс відтворювальних якостей свиноматки (індекс М. Д. Березовського) $(r=0,415)$.

Розрахунок економічної ефективності використання свиноматок великої білої породи різного рівня адаптації свідчить, що максимальну прибавку продукції одержано від тварин класу М- (+5,71\%) (табл. 3).

Економічна ефективність використання свиноматок різних класів розподілу за індексом «рівень адаптації»

\begin{tabular}{|c|c|c|c|c|}
\hline $\begin{array}{l}\text { Клас розподілу за індексом } \\
\text { «рівень адаптації» }\end{array}$ & $\mathrm{n}$ & $\begin{array}{c}\text { Маса гнізда на дату відлучення у } \\
\text { віці } 28 \text { діб, кг }\end{array}$ & Прибавка додаткової продукції, \% & $\begin{array}{l}\text { Вартість додаткової продукції, } \\
\text { грн./гол/опорос }\end{array}$ \\
\hline Загальна вибірка & 60 & $77,0 \pm 1,02$ & - & - \\
\hline $\mathrm{M}^{+}$ & 10 & $75,5 \pm 1,90$ & $-1,94$ & $-47,83$ \\
\hline $\mathrm{M}^{0}$ & 34 & $76,7 \pm 1,52$ & $-0,38$ & $-9,37$ \\
\hline $\mathrm{M}^{-}$ & 15 & $81,4 \pm 1,37$ & $+5,71$ & $+140,80$ \\
\hline
\end{tabular}

Примітка: ціна реалізації молодняку на час проведення експериментальної частини досліджень дорівнювала 42,7 грн. за 1 ка живої маси

Вартість додаткової продукції, яку одержують від однієї свиноматки зазначеної групи становить +140,80 грн.

Висновки. 1. Встановлено, що свиноматки великої 
білої породи підконтрольного стада характеризуються достатньо високими показниками відтворювальних якостей та рівнем адаптації до умов інтенсивної технології експлуатації. Тривалість життя свиноматок основного стада становить 44,1 місяців, тривалість племінного використання - 32,8 місяців, індекс «рівень адаптації» - 11,87 балів. За показниками багатоплідності та маси гнізда на час відлучення тварини основного стада належать до I класу та класу еліта.

2. 3 урахуванням внутріпородної диференціації за індексом «рівень адаптації» свиноматки класу М- достовірно переважали ровесниць класу $\mathrm{M}^{+}$за тривалістю життя на $54,77 \%$, тривалістю племінного використання - 71,48 \%, індексом «рівень адаптації» - 66,09 \%.
3. Достовірну різницю між групами тварин зазначених класів встановлено за багатоплідністю $(2,0$ гол, $\mathrm{td}=2,22$; $\mathrm{P}<0,05)$, масою гнізда на час відлучення у віці 28 діб, кг $(5,9$ кг, (td=2,56; $\mathrm{P}<0,01)$, індексом відтворювальних якостей свиноматки (індекс М. Д. Березовського) (3,9 бала, $\mathrm{td}=2,60$; $P<0,01)$.

4. Коефіцієнти парної кореляції між ознаками, що характеризують рівень адаптації та відтворювальні якості свиноматок коливаються у межах від $-0,704$ ( $\mathrm{tr}=10,80)$ до $+0,982(\operatorname{tr}=213,05)$.

5. Використання свиноматок великої білої породи класу $\mathrm{M}^{-}$за індексом «рівень адаптації» забезпечує одержання максимальної прибавки продукції (+5,71\%).

\section{Список використаної літератури:}

1.Халак В. И. Эксплуатационная ценность свиноматок крупной белой породы и экономическая эффективность их использования. Актуальные направления инновационного развития животноводства и современных технологий пролдуктов питания: материалы междунар. науч.-практ. конф. (пос. Персиановский, Донской ГАУ 27 ноября 2020 г.). 2020. С. 24-29.

2.Халак В. І. Нові методи інтегрованої оцінки свиноматок за показниками відтворювальних якостей. Зернові культури. 2020. Том 4. № 2. С. 396-403. https://doi.org/10.31867/2523-4544/0149

3.Ващенко П. А., Березовський М. Д., Небилиця М. С. Визначення племінної цінності свиней за використання лінійних моделей : Методичні рекомендації. Полтава: Інститут свинарства і агропромислового виробництва НААН., 2015. 12 с.

4.Коваленко Т. С. Удосконалення оцінки продуктивних і племінних якостей свиней за селекційними індексами : автореф. дис. на здобуття наук. ступеня канд. с.-г. наук : спец. 06.02.01 «Розведення та селекція тварин». Полтава, 2011. 17 с.

5.Березовський М. Д. Проблемні питання з удосконалення племінного свинарства в Україні та їх вирішення. Свинарство: міжвідомчий тематичний науковий збірник Інституту свинарства і АПВ НААН. Полтава, 2014. № 64. С. 37-48.

6.Ващенко П. А. Племінна цінність свиней. Свинарство: міжвідомчий тематичний науковий збірник. Полтава, 2011. Вип. 59. С. 28-32.

7.Шульга Ю. І. Топчій Л. І., Попов В. М. Адаптаційна здатність свиней української степової білої породи. Таврійський науковий вісник. Херсон: Грінь Д. С., 2011. Вип. 76. Ч. 2. С. 67-71.

8. Толоконцев А. Воспрозводительные и адаптационные качества свиней. Животноводство России. 2010. № 4. С. 33.

9.Топіха В. С., Коновалов І. В. Адаптаційні особливості свиней різних порід в умовах ВАТ Племзавод «Степной» Запорізької області. Вісник аграрної науки Причорномор'я. Миколаїв: МДАУ, 2009. Вип. 4 (51). С. 203-207.

10. Кислинская А. И., Калиниченко Г. И., Шакун А. П., Тышко Н. И. Оценка естественной резистентности организма свиней крупной белой породы венгерской селекции в период адаптации. Современные тенденции и технологические инновации в свиноводстве: материалы XIX междунар. науч.-практ. конф. Горки: БГСХА, 2012. С. 78-83.

11. Смирнов В. С. Оценка адаптации свиноматок к интенсивному воспроизводству. Зоотехния. 2003. № 7. С. 22 25.

12. Ващенко П. А. Прогнозування племінної цінності свиней на основі лінійних моделей селекційних індексів та ДНК-маркерів: автореф. дис.. на здобуття наук ступеня д-ра с.-г. наук : спец. 06.02 .01 «Розведення та селекція тварин». Миколаїв, 2019. 43 с.

13. Методика определения экономической эффективности использования в сельском хозяйстве результатов научно-исследовательских работ, новой технологи, изобретений и рационализаторских предложений. Москва. ВАИИПИ, 1983. 149 c.

14. Лакин Г.Ф. Биометрия. Москва. Высшая школа. 1990. 352 с

\section{References:}

1. Khalak V.I. 2020. Ekspluatatsionnaya tsennost' svinomatok krupnoy beloy porody i ekonomicheskaya effektivnost' ikh ispol'zovaniya. [The operational value of large white breed sows and the economic efficiency of their use] Aktual'nyye napravleniya innovatsionnogo razvitiya zhivotnovodstva i sovremennykh tekhnologiy prolduktov pitaniya: materialy mezhdunar. nauch.-prakt. konf. (pos. Persianovskiy, Donskoy GAU 27 noyabrya 2020 g.). pp. 24-29.

2. Khalak V.I. 2020. Novi metody intehrovanoyi otsinky svynomatok za pokaznykamy vidtvoryuval'nykh yakostey. 2020. [New methods of integrated assessment of sows by indicators of reproductive qualities] Zernovi kul'tury. Vol. 4. №2. Dnipro, «Nova ideolohiya», pp. 396 - 403.(doi.org/10.31867/2523-4544/0149).

3. Vashchenko P.A., Berezovs'kyy M.D., Nebylytsya M.S. 2015. Vyznachennya pleminnoyi tsinnosti svyney za vykorystannya liniynykh modeley. [Determination of breeding value of pigs using linear models]:Metodychni rekomendatsiyi. Poltava: Institute of Pig Breeding and Agroindustrial Production NAAS,. 12 p.

4. Kovalenko T.S. Udoskonalennya otsinky produktyvnykh i pleminnykh yakostey svyney za selektsiynymy indeksamy. 2011. [Improving the assessment of productive and breeding qualities of pigs by selection indices] avtoref. dys. na zdobuttya nauk. 
stupenya kand. s.-h. nauk : spets. 06.02.01 «Rozvedennya ta selektsiya tvaryn». Poltava, 17 p.

5. Berezovs'kyy M.D. Problemni pytannya z udoskonalennya pleminnoho svynarstva v Ukrayini ta yikh vyrishennya. 2014. [Problematic issues of improvement of breeding pig breeding in Ukraine and their solution] Svynarstvo: mizhvidomchyy tematychnyy naukovyy zbirnyk Instytutu svynarstva i APV NAAN. Poltava, № 64. pp. 37-48.

6. Vashchenko P.A. Pleminna tsinnist' svyney. 2011. [Breeding value of pigs]. Svynarstvo: mizhvidomchyy tematychnyy naukovyy zbirnyk. Poltava,. vol. 59. pp. 28-32.

7. Shul'ha Y.U., Topchiy L. I., Popov V.M. 2011. Adaptatsiyna zdatnist' svyney ukrayins'koyi stepovoyi biloyi porody. 2011. [ Adaptation ability of pigs of Ukrainian steppe white breed] Tavriys'kyy naukovyy visnyk, Kherson. vol. 76. pp. 67-71.

8. Tolokontsev A. 2010. Vosprozvoditel'nyye i adaptatsionnyye kachestva sviney [Reproductive and adaptive qualities of pigs] Zhivotnovodstvo Rossii. — № 4. p. 33.

9. Topikha V.S., Konovalov I.V. 2009. Adaptatsiyni osoblyvosti svyney riznykh porid v umovakh VAT Plemzavod «Stepnoy» Zaporiz'koyi oblasti. [Adaptation features of pigs of different breeds in terms of JSC Breeding "Stepnoy" Zaporozhye region] Visnyk ahrarnoyi nauky Prychornomor'ya. Mykolayiv: MDAU. — vol. 4 (51). pp. 203-207.

10. Kislinskaya A.I., Kalinichenko G.I., Shakun A.P., Tyshko N.I. 2012. Otsenka yestestvennoy rezistentnosti organizma sviney krupnoy beloy porody vengerskoy selektsii v period adaptatsii [Assessment of the natural resistance of the organism of pigs of large white breed of Hungarian selection during the adaptation period] Sovremennyye tendentsii i tekhnologicheskiye innovatsii $v$ svinovodstve: materialy XIX mezhdunar. nauch.-prakt. konf. — Gorki : BGSKHA, pp. 78-83.

11. Smirnov V.S. Otsenka adaptatsii svinomatok k intensivnomu vosproizvodstvu. 2003. [Assessment of adaptation of sows to intensive reproduction] Zootekhniya. № 7. pp. 22- 25

12. Vashchenko P.A. 2019. Prohnozuvannya pleminnoyi tsinnosti svyney na osnovi liniynykh modeley selektsiynykh indeksiv ta DNK-markeriv [Prediction of breeding value of pigs based on linear models of selection indices and DNA markers]: avtoref. dys. na zdobuttya nauk. stupenya d-ra s.-h. nauk: spets. 06.02.01 «Rozvedennya ta selektsiya tvaryn». Mykolayiv.

13. Metodika opredeleniya ekonomicheskoy effektivnosti ispol'zovaniya $v$ sel'skom khozyaystve rezul'tatov nauchnoissledovatel'skikh rabot, novoy tekhnologii, izobreteniy i ratsionalizatorskikh predlozheniy. 1983. [Methods for determining the economic efficiency of the use in agriculture of the results of scientific research, new technology, inventions and rationalization proposals]..- M.: VAIIPI.

14. Lakin G.F. 1990. Biometriya. [Biometrics], M.: Vysshaia shkola. 352.

Khalak Viktor Ivanovych, Candidate of Agricultural Sciences, Art. Researcher SI Institute of Grain Crops NAAS of Ukraine, (Dnipro, Ukraine)

Reproductive qualities of sows of large white breed of different intrabreed differentiation according to the index "level of adaptation" and economic efficiency of their use

The paper presents the results of studies of long-term adaptation and reproductive qualities of sows of large white breed, calculated indicators of variability of traits and their correlation, as well as the economic efficiency of research results. The experimental part of the work was carried out in agricultural formations of Dnipropetrovsk region (LLC "AF Dzerzhinets", LLC "Renaissance") and livestock laboratories of the State Institution Institute of Grain Crops NAAS. The work was performed according to IPA NAAS №30 "Innovative technologies of breeding, industrial and organic production of pig products (" Pig breeding "). The object of the study was the main sows of the large white breed. Evaluation of animals of the specified production group and breed on indicators of level of adaptation and reproductive qualities was carried out taking into account the following quantitative signs: life expectancy (TJ), months; duration of breeding use (MSW), months; received farrowings for the period of breeding use, received total piglets, heads; fertility, heads; nest weight at the time of weaning at the age of 28 days, $\mathrm{kg}$; safety of piglets before weaning, \%; The index "level of adaptation was calculated according to the method of V.S. Smirnov. (2003), index of reproductive qualities of sows according to the method of M.D. Berezovs'ky (P.A. Vashchenko, 2019). It was found that the life expectancy of sows of the main herd is 44.1 months, the duration of breeding use - 32.8 months, the index "level of adaptation" - 11.87 points. According to the indicators of fertility and nest weight at the time of weaning, the animals of the main herd belong to the I class and the elite class. Taking into account the intra-breed differentiation according to the index "level of adaptation" sows of class M-significantly outperformed peers of class $M+$ in terms of life expectancy, duration of breeding use and the index "level of adaptation" by an average of $64.11 \%$. A significant difference between groups of animals of these classes was found in terms of fertility (2.0 heads, td = 2.22), "nest weight at the time of weaning at the age of 28 days, $\mathrm{kg}$ " (5.9 $\mathrm{kg}, \mathrm{td}=2.56)$, index of reproductive qualities of the sow (index of MD Berezovsky) (3.9 points, $t d=2.60$ ). Pairwise correlation coefficients between traits that characterize the level of adaptation and reproductive qualities of sows range from -0.704 ( $\mathrm{tr}=10.80)$ to $+0.982(\mathrm{tr}=213.05)$. The use of sows of large white breed class $M$ - according to the index "level of adaptation" provides the maximum increase in production ( $+5.71 \%)$.

Key words: sow, life expectancy, duration of breeding use, reproductive qualities, index, level of adaptation, economic efficiency, variability, correlation.

Дата надходження до редакції: 18.01.2021 р. 